\title{
Mindeord til Per-Uno Ågren
}

\author{
ERIK HOFRÉN*
}

\author{
Den kendte, svenske museolog Per-Uno Ågren døde sommeren 2008. \\ Han var redaktør af Nordisk Museologi fra 1993 til 2004 og opbygge- \\ de museologien ved Umeå Universitet.
}

Erik Hofrén har skrevet disse mindeord i forbindelse med Per-Uno Ågrens pludselige død:

Sommaren hade kommit till Lappnäset och lommarna $i$ Vàngsjön, berättar Britta för mig om den dag då Per-Uno gick bort. Han tyckte om tystnaden $i$ storskogen och det kommer för mig att jag tyckte mycket om att dela tystnad med honom; som vänner kan trygga i förvissning om att samtalet fortsätter.

Det var genom arbetet vi blev vänner, en gemenskap som sträckte sig över mainga år i tro och tvivel på museets mål och mening. Med museologin ville vi föra erfarenhetens talan i akademiska salar med genklang i museernas offentligheter.

När Per-Uno formulerade museologins tre dimensioner, den historiska, den sociologiska och den kommunikativa bands de samman av hans samhälleliga engagemang.

Per-Uno var en brobyggare, den nordiska gemenskapen var honom viktig, nordist men också internationalist, uppdrag och seminarier förde honom till många länder där han vann nya vänner. Sitt Västerbotten bar han ständigt med sig.

Han hade en känslighet, en generositet som värmde och en torr och underfundig humor som inspirerade.
Jag tror man kommer honom särskilt nära när han skriver om det medium som kanske framförallt var hans - fotografiet. Per-Uno ville en humanistisk fotografi, en undersökande fotografi. Med hans ord - Den humanistiska fotografin är angelägen om sin integritet $i$ ett frigörande studium av människans verklighet. Den har alltid stätt inför den utmaning som som ett förtigande och utestängande inneburit.

Det var så han såg museet - ett humanistiskt museum angeläget om sin integritet $i$ ett frigörande studium av människans verklighet.

Hösten har kommit och lommarna lyfter på sin flykt mot havet och snart ligger Vangsjön $i$ isens grepp.

Vid Umeå universitet pågår nu ett avhandlingsarbete $i$ museologi om den svenska museiutvecklingen 1965-1995.

* Erik Hofrén, museolog

Address: Knopgatan 13, S-60385 Norrköping

E-mail: e.hofren@telia.com 